\title{
高职院校基于成果导向教育模式下教学方法的应用研究
}

\author{
白凤伟 张岩 卓娜王泽宇 \\ 锡林郭勒职业学院
}

DOI:10.32629/jief.v2i4.1326

[摘 要] 教学方法, 是教学过程中教师与学生为实现教学目的和教学任务要求, 在教学活动中所采取的行为方式的总称。包括问题法、谈论 法、演示法、实验法、讲授法、实习法等。受到招生条件的制约, 高职院校相对于大学本科院校, 在教学管理制度上较为严格, 这些从大学 录取志愿中落选的学生, 在自主学生的能力上较为欠缺, 这就要求教师在教学过程中更多的强调适度教育, 教学内容的灌输与课堂环境的协 调成为每个高职教师的职责。在学校倾向于制度管理与建设的同时, 教学内容本身受到了忽视, 使得教师不愿意为新的教学方法而对课堂的 组织与纪律承担责任。久而久之, 形成了固化的教学模式。具体表现为: 在理论课教学中, 教师以讲授教学法为主, 伴随课堂提问与测试, 教师很少与学生沟通; 在实践课教学中, 教师以讲解与演示为主, 有些教师省略了演示环节, 直接进入学生实操训练, 在教学方法上, 很少 进行分组合作、项目导向等方法, 教学方法单一。陈旧的教学方法一旦形成, 很少会有教师愿意革新, 导致很多适合于高职院校的教学方法 没有得到应用，严重影响了教学效果

[关键词] 高职院校; 教学方法; 应用研究

中图分类号: G712.3 文献标识码: A

在中国传统教学中，教师处于教学过程的主导地位，所以在教法与 学法中, 教法处于主导地位。而成果导向教育模式则将教学中的主导地 位还给学生, 其侧重点在于学生的学习成果, 强调学生的实际动手能力。 因此, 善用教学方法才能在成果导向教育模式下进行合理的课程设计。

\section{2 本课题国内外研究状况}

如何使课堂教学内容现代化已成为各国课堂教学改革研究者首要考 虑的问题. 从国外近 30 年来的课堂教学改革来看, 虽然由于指导思想, 改 革方案不同, 改革内容和幅度也不相同, 但这些国家在吸收科技新成果, 使课堂内容现代化上是相同的. 将科技新成果纳人传统的学科体系中, 是 作局部性的改良, 还是必须对传统学科体系进行彻底的改造. 从国外关于 课堂内容现代化所采取的方式上看, 主要表现为两种观点: 其一, 压缩旧 有的课堂内容; 其二, 彻底改造旧有课堂。

美国职业技术教育教学内容面向岗位工作的需要, 针对岗位职业的 实际, 在做中学, 在学中做, 边做边学, 教, 学, 做合一, 手, 口, 脑并用, 加强 实践教学环节, 始终是美国职教教学改革的主旋律. 实践, 校外实习都特 别强调. 由于他们重视把教学与实践融为一体, 使学生的理论知识, 实践 活动融会贯通, 极大提高了毕业生上岗的适应能力.

国内高职院校也不同程度的进行了课程内容改革, 有的是大量削减 文化课, 增加专业课; 有的学校进行课程整合, 形成核心课程体系. 总之, 无论采用哪种形式的课程内容改革, 都”要着重职业技能的训练”, 突出其 应用性与基础观.

\section{3 本课题研究的主要目标与内容}

3.1 研究目标:

3. 1.1 通过本课题研究, 进一步探求基于成果导向教育模式下教学 方法研究, 建立高职教学方法理论体系。

3. 1.2 通过本课题研究, 进一步深化高职教育教学方法改革, 促进 教师教学水平的提高, 促进专业建设与发展。

3.1.3 通过本课题研究, 建立一整套衡量教师教育教学水平和学生 学习效果的标准, 树立现代育人理念。

3.1. 4 通过本课题研究, 提高教师科研水平, 倡导不断进取, 改革 创新的精神。

3.2 研究内容:

3.2.1 如何适当选用教学方法

教法本无优劣之分, 也没有一定的使用标准或服务对象, 也正因为 这样, 教法才有了生命力。成果导向教育模式引进的新教法层出不穷, 但对我们来说, 并不都是适用的。所以教师在选用教学方法时要根据不 同的教学环节, 选用适当的教学方法, 否则, 就会哗众取宠, 得不偿失。

3.2.2 重视课堂教学环节设计

成果导向教育模式重视教学单元的教学环节设计, 而教学方法则是
为完成每一个教学环节所采取的具体的方式方法。也就是说, 教学环节 强调做什么, 教学方法强调怎样做。

\subsection{3 以学法带动教法}

在课堂教学中, 正确地使用教法, 常常能使教学达到事半功倍的效 果, 但 “以学生为主体” 绝不能成为一句空话, 成果导向教育模式要求 教师把课堂还给学生, 这就要求学生具有充分的自我学习能力, 如何培 养学生这种能力呢, 还是要教师在教学方法上放手, 让学生充分运用自 主学习、创意学习、行动学习、合作学习等学习方法, 将教学方法与学 习方法合理贯穿在教学环节中。

\section{4 本课题研究方法与实施步骤:}

4. 1 研究方法:

本课题研究采用调查研究法, 分析比较法, 文献研究法, 总结研究 法, 实验法等方法。

其具体操作如下: 首先组织全体课题组成员查阅资料系统学习成果 导向教育模式教学方法理论体系, 学习教育学、心理学关于教学原则、 教学模式的理论和青少年个性心理特征对学习的影响理论, 在此基础上 广泛调研高职院校的成果导向教育模式, 收集相关资料, 课题组将不同 教学方法分解到不同专业进行试验, 设置对照班级, 对试验结果分析比 较, 通过不断总结, 形成阶段性论文和研究报告。

4.2 实施步骤

4.2.1 前期准备及开题阶段。

时间为 2018 年 1 月至 2018 年 3 月, 本阶段主要是制定开题计划, 准备开题报告, 安排工作分工, 召开开题论证会。

4. 2.2 专题研究阶段:

时间为 2018 年 4 月至 2018 年 10 月, 本阶段主要是按分工要求开展 研究工作, 收集一手资料, 形成研究论文。

4.2.3 综合研究阶段:

时间为 2018 年 11 月至 2019 年 11 月，课题组成员进行整理归档, 形成课题研究报告, 专著和论文。

4. 2.4 课题结题阶段:

2019 年 12 月至 2020 年 1 月, 邀请专家对课题进行鉴定。

[参考文献]

[1]黄敏雄.汽车类高职院校校企文化对接的创新与实践 [J].食品研 究与开发,2020,41(17):230.

[2]韩海姣。“双高计划”背景下高职院校教师队伍建设研究[J].今日 财富,2020(17):136-137.

[3]张欢欢,罗瑞,彭小珊.高职院校健康管理专业设置背景及职业前景 研究[J].检验医学与临床,2020,17(16):2424-2426. 